\title{
PROGNOSTIC VALUE OF CLINICAL SCORES, PENTRAXIN- 3 AND C - REACTIVE PROTEIN IN TOXIN-RELATED ACUTE LUNG INJURY AND ACUTE RESPIRATORY DISTRESS SYNDROME
}

\author{
Walaa Gomaa Abdelhamid, Hoda Mohamed Salah Eldin, Manal A Abd-Elkarim Mary \\ Sabry Abd EI Messih \\ Poison Control Center- Forensic Medicine and Clinical Toxicology Department, Faculty of \\ Medicine, Ain Shams University, Cairo, Egypt.
}

Corresponding Author

Hoda Mohamed Salah Eldin

Department of Forensic medicine and Clinical Toxicology

Faculty of Medicine, Ain Shams University, Cairo, Egypt.

Phone: 00201002024113

Email: hodasalah1974@gmail.com

\begin{abstract}
:
Objectives: Toxin-related ALI (Acute lung injury) and/or ARDS (Acute respiratory distress syndrome) is challenging to critical care physicians. This study aimed at evaluation of clinical scores, pentraxin-3 (PTX3) and C-reactive protein (CRP) as predictors of severity and outcome in toxin - related ALI/ARDS in 50 acutely intoxicated patients. Material and Method: Laboratory variables were assessed on day1, day 2, day3 and endpoint. Clinical data were employed in the calculation of APACHE II score, Lung Injury score (LIS), Sequential Organ Failure Assessment (SOFA) score. Results: Several variables were associated with poor outcome in the poisoned ARDS patients like prolonged ICU stay, prolonged duration of mechanical ventilation, low $\mathrm{PO}_{2} / \mathrm{FiO}_{2}$ and $\mathrm{SO}_{2} / \mathrm{FiO}_{2}$ ratios, high APACHE II, SOFA and lung injury scores on the $1^{\text {st }}$ day, elevated plasma PTX3 levels on the $1^{\text {st }}$ day, and elevated serum CRP levels after 24 hours of admission. APACHE II score surpassed other scores as an excellent predictor of outcome within the $1^{\text {st }} 24$ hours of admission. PTX3 represented an early marker of severity, and its levels correlated with parameters of lung injury, systemic organ failure and outcome. Conclusion: Early combination of plasma PTX3 and predictive scores could help in identifying patients at risk of severe fatal toxin - related ARDS.

Key words: Toxin-related, acute lung injury, acute respiratory distress syndrome, pentraxin3, CRP APACHE II, SOFA

\section{INTRODUCTION}

Acute lung injury with or without progression to ARDS is a common occurrence from poisoning. Toxinrelated ALI/ARDS is a clinical syndrome

which might be caused by direct damage to the respiratory cells at the alveolar level or indirectly through inflammation mediators due to xenobiotics exposure leading to widespread
\end{abstract}


lung inflammation with impaired gas exchange (Stolbach \&Hoffman, 2015).

Information on toxic ARDS is limited and estimates of incidence and mortality rates deduced from case reports, observational studies and (inter)national registries, are likely to represent only a minute fraction of the true incidence. As with most druginduced diseases, due to pathological non-specificity or physician unawareness, diagnosis is often difficult and is mostly based on exclusion of all other possible causes (Raissy and Harkins, 2014; De Lange,2015).

Despite high current overall hospital mortality of ARDS which approximates 40-50\%, a little has been published concerning toxin-related ALI/ARDS. This warrants the attention to the risk factors and prognostic criteria of ALI/ARDS in acutely intoxicated patients (Fanelli et al., 2013).

Owing to limited health care resources and increased cost of health management, predicting and early diagnosis of ALI/ARDS is considered crucial. However, clinical skills per se are usually insufficient in early stages of the disease. On the other hand, monitoring of appropriately selected laboratory biomarkers is minimally invasive and avoids the possibility of interobserver variability (Ware et al., 2000).

Pentraxin 3 (PTX3) and C-reactive protein (CRP) are acute-phase proteins, acting as inflammatory mediators in response to pro-inflammatory signals (Bottazzi et al., 2009). High serum PTX3 and CRP levels have been associated with increasing mortality in ARDS in critically ill patients. In addition, they have been shown to serve as early biomarkers in acute lung injury (Cypel et al., 2010 and Huttunen et al., 2011).

\section{AIM OF THE WORK}

This study aims at: assessment of toxin - related ALI/ARDS in patients admitted to the ICU of the Poison Control Center of Ain Shams University hospitals (PCC), during the period starting from January 2013 and ending in December 2015, with evaluation of clinical scores, pentraxin-3 (PTX3) and $\mathrm{C}$-reactive protein (CRP) as predictors of severity and outcome in toxin-related ALI/ARDS.

\section{MATERIAL \& METHOD}

The present study was planned as a cross-sectional hospital-based observational study.

- Study group: Fifty acutely intoxicated patients, of both sex, were enrolled in this study. All patients were admitted to the ICU of Poison Control Center of Ain Shams University hospitals (PCCA) and intubated with suspected acute lung injury (according to lung injury score) (Udobi et al., 2003). Based on the possibility of alteration in lung parameters and/or in the levels of the measured biomarkers, exclusion criteria included: transfer from another ICU and/or intubation for a period longer than 24 hours, death within 24 hours of ALI diagnosis, ages under 18 years and above 65 years, pregnancy, history of respiratory, cardiovascular, renal, or hepatic disease, pulmonectomy or pulmonary resection within 1 month before endotracheal intubation, active 
malignancy, and immunosuppression of any cause.

- Ethical Considerations: An informed consent was obtained from the patients' next of kin. The study was approved by the research ethics committee of Faculty of Medicine Ain Shams University.

- Clinical data: Age, sex, type of agent(s) responsible for intoxication, mode \& route of poisoning, and delay time were recorded at enrollment. This is in addition to duration of admission in the ICU, total period of hospitalization and outcome (including complete recovery, recovery with any type of organ failure as identified in Table (2) or death).

- Examination of the patients was carried out at the time of presentation to the PCC and periodically for follow up according to the type and severity of poisoning.

- Investigations were performed according to specific requirements of each patient following the guidelines of the PCC protocols. General laboratory investigations (done routinely in the ICU) included random blood sugar, serum sodium and potassium, serum urea and creatinine, serum ALT and AST, serum bilirubin, complete blood picture, and arterial blood gases. Specific toxicological investigations were performed according to type of toxic agent e.g. pseudocholinestrase enzyme levels in cases of organophosphorus intoxication. Serum biomarkers namely penteraxin-3 and CRP were measured.

- All clinical and laboratory variables were performed and recorded on $1^{\text {st }} 24$ hours after endotracheal intubation, repeated after 24 hours from the initial assessment, 3 days later, and lastly at the time of patient's discharge, referral or death.

- Variables of different days of the study were employed in the calculation of three scores: Acute Physiology and Chronic Health Evaluation II (APACHE II) score (Knaus et al, 1981), Lung Injury score (LIS) (Murray et al., 1988), Sequential Organ Failure Assessment (SOFA) score (Vincent et al., 1996). APACHE II score was calculated during the $1^{\text {st }} 24$ hours after admission using the worst measured values. Number of organ failure (whether respiratory, cardiovascular, hepatic, renal or hematological) according to Goris et al., (1985), SOFA score and LIS were calculated at the time of each sample collection.

- Assessment of Pentraxin-3 (PTX3): Levels of PTX3 were measured in plasma by a sandwiched enzymelinked immunosorbent assay. The assay was only specific for human PTX3 and did not cross react with CRP with a sensitivity of $23 \mathrm{pg} / \mathrm{ml}$ and reference range of $\leq 2 \mathrm{ng} / \mathrm{ml}$ (Mauri et al., 2008).

- Assessment of CRP: Levels of PTX3 were measured in serum by high sensitivity enzyme-linked immunosorbent assay with reference range of $68-8200 \mathrm{ng} / \mathrm{ml}$ (Liu et al., 2013).

\section{RESULTS}

LIS was used as a baseline measure to identify toxin - related ALI/ARDS in patients enrolled in this study. By the end of the study, in relation to lung injury score, 13 patients (26\%) completely recovered with no lung injury. ALI 
criteria persisted in 18 patients $(36 \%)$ where $50 \%$ of them died while 19 patients $(38 \%)$ showed progression to ARDS with no survivors. Patients were sub-classified regarding their outcome into 2 groups as follows:

- Survivors: included 22 patients representing $44 \%$ of the total number of patients. Nine of which developed different types of organ failure including respiratory, cardiovascular, renal, hepatic and hematological while 13 patients were free of complications.

- Non-survivors: included 28 patients representing $56 \%$ of the total number of patients.

Table (1) shows demographic data, intoxication data, period of hospital stay and treatment of all studied patients. The mean age value for all patients was 31.94 \pm 10.28 years. Males were slightly more affected than females. Neither age nor sex showed any significant difference between survivors and non-survivors. The majority of patients $(70 \%)$ did not give history of neither medical nor psychological co-morbidities while $14 \%$ had medical problems in the form of hypertension, previous stroke and peptic ulcer. Psychiatric problems, mainly depression and psychosis, were present in $16 \%$ of all patients.

Suicidal intoxication represented the main mode of intoxication accounting for $48 \%$, followed by addictive overdose (34\%). Accidental mode did not exceed $18 \%$.Ingestion was the commonest route of intoxication accounting for $78 \%$ followed by others. Organophosphates topped the list of toxic agents accounting for $44 \%$ of all cases and 57\% of all deaths followed by tramadol representing $26 \%$ of all cases. No significant difference was observed as regards type of toxic agents, route of intoxication and delay time before arrival to hospital between survivors and non-survivors.

The total period of stay in the PCC was not significantly different among survivors and non-survivors. However; there was a significant difference in the duration of admission in the ICU and the duration of mechanical ventilation between both groups. Steroids and muscle relaxants were included in the treatment protocols of $52 \%$ and $12 \%$ of patients respectively with no difference observed of either modalities regarding the percentage of death among the studied individuals.

Assessment of number and types of organ failure on different days revealed predominance of respiratory failure throughout the whole period of stay, either alone or combined with other organ failure. In addition, significant increase in percentage of death was found with increasing number of organ failure on $2^{\text {nd }}, 5^{\text {th }}$ day and finally.

On the $1^{\text {st }}$ and $2^{\text {nd }}$ days of the study, isolated respiratory failure was observed in $54-58 \%$ of the studied patients while its combination with cardiovascular, hepatic or renal dysfunction was found in $22-24 \%$ of patients. On the $5^{\text {th }}$ day, $30 \%$ of the patients suffered from respiratory failure only and $30 \%$ did not show any organ affection. By the end of the study, multi-organ failure was obvious in $44 \%$ of the patients. No organ failure was documented in $38 \%$ of patients while $18 \%$ had isolated respiratory failure (Table 2).

In the current study, a positive correlation was found between $\mathrm{PaO} 2 / \mathrm{FiO} 2$ and $\mathrm{SpO} 2 / \mathrm{FiO} 2$ ratios among 
survivors and non survivors on all days and at the end of the study (Table 3). No significance was observed between survivors and non survivors regarding $\mathrm{PO} 2 / \mathrm{FiO} 2$ and $\mathrm{SpO} / \mathrm{FiO} 2$ ratios on the 1st day, however significance was obvious on other days (Table 4).

All mean values of APACHE II score, its estimated or predicted death rate, SOFA score and LIS were significantly higher among non-survivors compared to survivors (Table 5). On the 1st day, APACHE II score was the most sensitive and specific compared to SOFA score and LIS. SOFA score was more sensitive, but less specific than LIS on the $2^{\text {nd }}$ day. By the end of the study, both scores were $100 \%$ sensitive and specific (Table 6).

All mean values of PTX3 were significantly higher among non survivors compared to survivors with a peak on day (1). Though its levels dropped on day (2) and day (5), they did not return to the normal values. In contrast, CRP levels started to increase on the 2nd day and continued on the 5th day being significantly much higher among non survivors than survivors.PTX3 was more sensitive and specific compared to CRP when measured on different days. However, CRP was $100 \%$ sensitive and specific later. An inverse correlation was found between PTX3 and CRP on all days among both survivors and nonsurvivors (fig. 1 \& 2, table 7). A significant negative correlation between PTX and APACHE score was shown on 1 st day among non-survivors. A significant negative correlation was found between PTX and number of organ failure on the 1st day among survivors. A significant positive correlation was observed between PTX and $\mathrm{PaO} 2 / \mathrm{FiO} 2$ ratio on the 5th day among non-survivors, while an inverse significant correlation was noted between PTX and $\mathrm{SpO} 2 / \mathrm{FiO} 2$ on the 5th day among survivors (table 8 ). 
Table (1): Demographic data, intoxication data, period of hospital stay and treatment in the study group

\begin{tabular}{|c|c|c|c|c|c|c|}
\hline & & $\begin{array}{c}\begin{array}{c}\text { Overall } \\
\text { patients } \\
(n=50)\end{array} \\
\text { (n) }\end{array}$ & $\begin{array}{l}\text { Survivors } \\
(\mathbf{n}=\mathbf{2 2})\end{array}$ & $\begin{array}{c}\text { Non- } \\
\text { survivors } \\
(\mathbf{n}=\mathbf{2 8})\end{array}$ & & $\begin{array}{c}\text { p- } \\
\text { value }\end{array}$ \\
\hline Age(years) & & $31.94 \pm 10.28$ & $32.23 \pm 10.19$ & $31.7 \pm 10.53$ & $0.173^{* *}$ & 0.863 \\
\hline \multirow{2}{*}{ Gender } & Male & $26(52 \%)$ & 14 & 12 & \multirow{2}{*}{$2.131^{*}$} & \multirow{2}{*}{0.166} \\
\hline & Female & $24(48 \%)$ & 8 & 16 & & \\
\hline \multirow{3}{*}{$\begin{array}{c}\text { Mode of } \\
\text { poisoning }\end{array}$} & Suicidal & 24 & 7 & 17 & \multirow{3}{*}{$4.571 *$} & \multirow{3}{*}{0.11} \\
\hline & Addiction & 17 & 9 & 8 & & \\
\hline & Accidental & 9 & 6 & 3 & & \\
\hline \multirow{3}{*}{$\begin{array}{c}\text { Route of } \\
\text { poisoning }\end{array}$} & Oral & 39 & 15 & 24 & \multirow{3}{*}{$2.536^{*}$} & \multirow{3}{*}{0.115} \\
\hline & Inhalation & 7 & 4 & 3 & & \\
\hline & Injection & 4 & 3 & 1 & & \\
\hline \multirow{9}{*}{$\begin{array}{c}\text { Toxic } \\
\text { agents }\end{array}$} & Organophosphates & 22 & 6 & 16 & \multirow{9}{*}{$9.192 *$} & \multirow{9}{*}{0.085} \\
\hline & Tramadol & 11 & 5 & 6 & & \\
\hline & Carbon monoxide & 7 & 4 & 3 & & \\
\hline & Opiate & 4 & 3 & 1 & & \\
\hline & Methanol & 2 & 1 & 1 & & \\
\hline & $\begin{array}{c}\text { Tramadol \& } \\
\text { benzodiazepine }\end{array}$ & 1 & 1 & 0 & & \\
\hline & $\begin{array}{c}\text { Tramadol \& } \\
\text { antidepressant }\end{array}$ & 1 & 1 & 0 & & \\
\hline & $\begin{array}{l}\text { Phenothiazine \& } \\
\text { benzodiazepine }\end{array}$ & 1 & 1 & 0 & & \\
\hline & $\begin{array}{c}\text { Phenothiazine \& } \\
\text { antidepressant }\end{array}$ & 1 & 0 & 1 & & \\
\hline \multicolumn{2}{|c|}{ Delay time (hrs) } & $5.66 \pm 3.788$ & $5.68 \pm 4.79$ & $5.64 \pm 2.86$ & $0.036 * *$ & 0.972 \\
\hline \multirow{3}{*}{$\begin{array}{c}\text { Pre- } \\
\text { consultation } \\
\text { management }\end{array}$} & Negative & 29 & 13 & 16 & \multirow{3}{*}{$0.328^{*}$} & \multirow{3}{*}{0.937} \\
\hline & Mal & 15 & 7 & 8 & & \\
\hline & Proper & 6 & 2 & 4 & & \\
\hline \multirow{3}{*}{$\begin{array}{c}\text { Co- } \\
\text { morbidities }\end{array}$} & No & 35 & 14 & 21 & \multirow{3}{*}{$6.923^{*}$} & \multirow{3}{*}{0.657} \\
\hline & Psychological & 8 & 4 & 4 & & \\
\hline & Medical & 7 & 4 & 3 & & \\
\hline \multirow{3}{*}{$\begin{array}{c}\text { Period of } \\
\text { stay } \\
\text { (days) }\end{array}$} & PCC & $8.62 \pm 4.03$ & $7.55 \pm 3.58$ & $9.46 \pm 4.2$ & $1.706^{-} *$ & 0.095 \\
\hline & ICU & $7.88 \pm 4.25$ & $5.86 \pm 3.4$ & $9.46 \pm 4.2$ & ${ }^{-} 255^{* *}$ & 0.002 \\
\hline & Ventilation & $7.46 \pm 4.33$ & $4.9 \pm 2.96$ & $9.46 \pm 4.2$ & $4.303 * *$ & $\begin{array}{c}<0.00 \\
1\end{array}$ \\
\hline \multirow{2}{*}{ Treatment } & Steroids & 26 & 14 & 12 & $2.13^{*}$ & 0.166 \\
\hline & Muscle relaxants & 6 & 1 & 5 & $2.06^{*}$ & 0.211 \\
\hline
\end{tabular}

Data are presented as mean \pm standard deviation unless otherwise indicated. n: Number of patients, $*=\mathrm{X}^{2}$ (Chi square statistical analysis) $* *=t$ (Student's t test) p $>0.05$ = statistically non-significant 
Table (2): Types of organ failure at end-point.

\begin{tabular}{|l|c|c|c|}
\hline \multicolumn{1}{|c|}{$\begin{array}{c}\text { Types of organ failure at } \\
\text { endpoint }\end{array}$} & $\begin{array}{c}\text { Overall } \\
\text { patients } \\
(\mathbf{n = 5 0 )}\end{array}$ & $\begin{array}{c}\text { Survivors } \\
(\mathbf{n = 2 2})\end{array}$ & $\begin{array}{c}\text { Non-survivors } \\
(\mathbf{n = 2 8})\end{array}$ \\
\hline No & 19 & 19 & 0 \\
\hline Resp. & 9 & 1 & 8 \\
\hline Resp. \& CVS & 9 & 0 & 9 \\
\hline Resp., CVS \& Renal & 3 & 0 & 3 \\
\hline Resp. \& Hepatic & 3 & 1 & 2 \\
\hline Resp., CVS \& Hepatic & 2 & 0 & 2 \\
\hline Resp. \& Renal & 2 & 1 & 1 \\
\hline Resp., CVS, Renal \& Hepatic & 1 & 0 & 1 \\
\hline Resp., Renal \& Hepatic & 1 & 0 & 1 \\
\hline $\begin{array}{l}\text { Resp., CVS, Renal \& } \\
\text { hematological }\end{array}$ & 1 & 0 & 1 \\
\hline
\end{tabular}

n: Number of patients

Resp. $=$ Respiratory failure defined by $\mathrm{PaO}_{2} / \mathrm{FiO}_{2} \leqq 300 \mathrm{~mm} \mathrm{Hg}$

CVS = Cardiovascular failure in the form of prolonged hypotension (mean arterial pressure $\leqq 60 \mathrm{~mm} \mathrm{Hg}$ ) requiring correction by volume loads or vasoactive drugs Renal dysfunction: serum creatinine $>2 \mathrm{mg} / \mathrm{dl}$ and/or presence of artificial renal support Hepatic impairment: serum bilirubin $>2 \mathrm{mg} / \mathrm{dl}$ and/or ALT $>80 \mathrm{UI} / \mathrm{L}$ Hematological disorders: platelets count $<50 \times 10^{3} / \mathrm{mm}^{3}$

Table (3): Correlation between $\mathrm{PaO}_{2} / \mathrm{FiO}_{2}$ ratio and $\mathrm{SpO}_{2} / \mathrm{FiO}_{2}$ ratio on different days in acutely intoxicated patients under the study.

\begin{tabular}{|c|c|c|c|c|}
\hline \multirow{2}{*}{$\mathrm{SpO}_{2} / \mathrm{FiO}_{2}$ ratio } & \multicolumn{4}{|c|}{$\mathbf{P a O}_{2} / \mathrm{FiO}_{2}$ ratio } \\
\cline { 2 - 5 } & \multicolumn{2}{|c|}{ Survivors (n=22) } & \multicolumn{2}{|c|}{ Non-survivors (n=28) } \\
\cline { 2 - 5 } & $\mathbf{r}$ & $\mathbf{p}$ & $\mathbf{r}$ & $\mathbf{p}$ \\
\hline Day (1) & 0.163 & 0.469 & 0.216 & 0.27 \\
\hline Day (2) & 0.019 & 0.931 & 0.228 & 0.242 \\
\hline Day (5) & 0.581 & 0.005 & 0.62 & $<0.001$ \\
\hline End-point & 0.127 & 0.574 & 0.2 & 0.308 \\
\hline
\end{tabular}

n: Number of patients $\quad$ r: Correlation coefficient $\quad p>0.05=$ statistically non-significant 
Table (4): $\mathrm{PaO}_{2} / \mathrm{FiO}_{2}$ and $\mathrm{SpO}_{2} / \mathrm{FiO}_{2}$ in the studied poisoned patients recorded on $1^{\text {st }}$ day, $2^{\text {nd }}$ day, $5^{\text {th }}$ day and at end-point.

\begin{tabular}{|c|c|c|c|c|c|}
\hline Ratios & $\begin{array}{c}\text { Overall patients } \\
(n=50)\end{array}$ & Survivors $(n=22)$ & $\begin{array}{c}\text { Non-Survivors } \\
(\mathbf{n}=\mathbf{2 8})\end{array}$ & $\mathbf{t}$ & $\mathbf{P}$ \\
\hline \multicolumn{5}{|c|}{ Day (1) } & \\
\hline $\mathrm{PaO}_{2} / \mathrm{FiO}_{2}$ & $224.27 \pm 89.94$ & $246.15 \pm 75.55$ & $207.77 \pm 27.7$ & 1.547 & 0.128 \\
\hline $\mathrm{SpO}_{2} / \mathrm{FiO}_{2}$ & $164.19 \pm 41.38$ & $166.85 \pm 49.49$ & $162.1 \pm 34.5$ & 0.4 & 0.691 \\
\hline \multicolumn{5}{|c|}{ Day (2) } & \\
\hline $\mathrm{PaO}_{2} / \mathrm{FiO}_{2}$ & $226.7 \pm 94.6$ & $281.38 \pm 102.7$ & $219.48 \pm 80$ & 2.406 & 0.02 \\
\hline $\mathrm{SpO}_{2} / \mathrm{FiO}_{2}$ & $196.9 \pm 43.27$ & $215.41 \pm 43.07$ & $182.4 \pm 38.18$ & 2.868 & 0.006 \\
\hline \multicolumn{5}{|c|}{ Day (5) } & \\
\hline $\mathrm{PaO}_{2} / \mathrm{FiO}_{2}$ & $274.6 \pm 127.98$ & $374.04 \pm 89.73$ & $196.5 \pm 95.3$ & 6.707 & $<0.001$ \\
\hline $\mathrm{SpO}_{2} / \mathrm{FiO}_{2}$ & $247.5 \pm 129.57$ & $359.18 \pm 110.96$ & $159.8 \pm 52.47$ & 8.403 & $<0.001$ \\
\hline \multicolumn{5}{|c|}{ End-point } & \\
\hline $\mathrm{PaO}_{2} / \mathrm{FiO}_{2}$ & $253.7 \pm 163.88$ & $428.74 \pm 41.99$ & $116.3 \pm 53.2$ & 6.757 & $<0.001$ \\
\hline $\mathrm{SpO}_{2} / \mathrm{FiO}_{2}$ & $265.76 \pm 181.57$ & $466.78 \pm 10.21$ & $107.82 \pm 31$ & 7.772 & $<0.001$ \\
\hline
\end{tabular}

n: Number of patients, $\mathbf{p}>\mathbf{0 . 0 5}=$ statistically non-significant, Data are presented as mean \pm standard deviation, $\mathrm{PaO}_{2} / \mathrm{FiO}_{2}=$ Partial arterial oxygen pressure/Fraction of inspired oxygen, $\mathrm{SpO}_{2} / \mathrm{FiO}_{2}=$ Pulse oximetric oxygen saturation/Fraction of inspired oxygen, $\mathrm{t}$ :

Student's t-test statistical analysis

Table (5): APACHE II score (and its estimated death rate) in the $1^{\text {st }} 24$ hours of admission, SOFA score and LIS recorded on $1^{\text {st }}$ day, $2^{\text {nd }}$ day, $5^{\text {th }}$ day and at end-point in the studied poisoned cases.

\begin{tabular}{|c|c|c|c|c|c|}
\hline \multirow[t]{2}{*}{ Scores } & $\begin{array}{c}\text { Overall patients } \\
(n=50)\end{array}$ & $\begin{array}{c}\text { Survivors } \\
(\mathbf{n}=\mathbf{2 2})\end{array}$ & $\begin{array}{c}\text { Non-survivors } \\
(\mathbf{n}=\mathbf{2 8})\end{array}$ & \multirow[t]{2}{*}{$\mathbf{t}$} & \multirow[t]{2}{*}{$\mathbf{P}$} \\
\hline & $\mathbf{M} \pm$ SD & M \pm SD & M \pm SD & & \\
\hline \multicolumn{6}{|c|}{ Day (1) } \\
\hline APACHE score & $23.08 \pm 6.51$ & $17.09 \pm 3.31$ & $27.79 \pm 4$ & -10.09 & $<0.001$ \\
\hline EDR\% & $47.02 \pm 20.8$ & $27.45 \pm 9.12$ & $62.4 \pm 12.8$ & -10.81 & $<0.001$ \\
\hline SOFA score & $6.5 \pm 2.19$ & $5.73 \pm 1.78$ & $7.11 \pm 2.33$ & -2.29 & 0.026 \\
\hline LIS & $1.35 \pm 0.39$ & $1.18 \pm 0.33$ & $1.48 \pm 0.39$ & -2.88 & 0.011 \\
\hline \multicolumn{6}{|c|}{ Day (2) } \\
\hline SOFA score & $6.54 \pm 2.67$ & $5.14 \pm 1.81$ & $7.64 \pm 2.74$ & -3.88 & $<0.001$ \\
\hline LIS & $1.41 \pm 0.46$ & $1.11 \pm 0.38$ & $1.64 \pm 0.37$ & -4.94 & $<0.001$ \\
\hline \multicolumn{6}{|c|}{ Day (5) } \\
\hline SOFA score & $6.18 \pm 4.3$ & $2.5 \pm 2.35$ & $9.07 \pm 3.3$ & -8.20 & $<0.001$ \\
\hline LIS & $1.64 \pm 0.92$ & $0.9 \pm 0.64$ & $2.2 \pm 0.66$ & -7.15 & $<0.001$ \\
\hline \multicolumn{6}{|c|}{ End-point } \\
\hline SOFA score & $6.7 \pm 6.03$ & $0.64 \pm 1$ & $11.5 \pm 3.36$ & -14.63 & $<0.001$ \\
\hline LIS & $1.61 \pm 1.3$ & $0.23 \pm 0.33$ & $2.69 \pm 0.48$ & -20.59 & $<0.001$ \\
\hline
\end{tabular}

n: Number of patients, Data are presented as mean \pm standard deviation, $t:$ Student's t-test statistical analysis $\mathbf{P}<\mathbf{0 . 0 5}=$ statistically significant, APACHE II score: Acute Physiology And Chronic Health Evaluation II score, EDR: Estimated Death Rate, SOFA score: Sequential Organ Failure score, LIS: Lung Injury score 
Table (6): Sensitivity, specificity, Area under curve (AUC) and cut off values of APACHE II score (on $1^{\text {st }}$ day), SOFA and lung injury scores on $1^{\text {st }}$ day, $2^{\text {nd }}$ day, $5^{\text {th }}$ day and at end-point in the studied poisoned cases.

\begin{tabular}{|c|c|c|c|c|}
\hline Scores & Sensitivity (\%) & Specificity (\%) & AUC & Cut off value \\
\hline \multicolumn{5}{|c|}{ Day (1) } \\
\hline APACHE II score & 96.4 & 100 & 0.99 & 21 \\
\hline SOFA score & 64.3 & 77.3 & 0.72 & 6.5 \\
\hline Lung injury score & 75 & 50 & 0.71 & 1.13 \\
\hline \multicolumn{5}{|c|}{ Day (2) } \\
\hline SOFA score & 78.6 & 68.2 & 0.79 & 5.5 \\
\hline Lung injury score & 71.4 & 72.7 & 0.83 & 1.38 \\
\hline \multicolumn{5}{|c|}{ Day (5) } \\
\hline SOFA score & 100 & 77.3 & 0.96 & 4.5 \\
\hline Lung injury score & 93 & 54.5 & 0.91 & 1.13 \\
\hline \multicolumn{4}{|c|}{ End-point } \\
\hline SOFA score & 100 & 100 & 1.0 & 5.5 \\
\hline
\end{tabular}

APACHE II score: Acute Physiology And Chronic Health Evaluation II score SOFA score: Sequential Organ Failure score, LIS: Lung Injury score, AUC: Area under curve

Table (7): Sensitivity, specificity, Area Under Curve (AUC) and cut off values of plasma Pentraxin 3 and serum CRP levels on $1^{\text {st }}$ day, $2^{\text {nd }}$ day and $5^{\text {th }}$ day in the studied cases.

\begin{tabular}{|c|c|c|c|c|}
\hline Biomarkers & $\begin{array}{c}\text { Sensitivity } \\
(\%)\end{array}$ & Specificity (\%) & AUC & $\begin{array}{c}\text { Cut off value } \\
(\mathbf{n g} / \mathbf{m l})\end{array}$ \\
\hline \multicolumn{5}{|c|}{ Day (1) } \\
\hline PTX3 & 100 & 100 & 1.0 & 5.5 \\
\hline CRP & 75 & 50 & 0.63 & 4950 \\
\hline \multicolumn{5}{|c|}{ Day (2) } \\
\hline PTX3 & 100 & 100 & 1.0 & 4.7 \\
\hline CRP & 75 & 63.6 & 0.77 & 8850 \\
\hline \multicolumn{7}{|c|}{ Day (5) } \\
\hline PTX3 & 100 & 100 & 1.0 & 4.3 \\
\hline CRP & 100 & 100 & 1.0 & 12450 \\
\hline
\end{tabular}

PTX3: Pentraxin 3

CRP: C - reactive protein

AUC: Area under curve 
Table (8): Correlation between PTX3 and clinical variables on different days in acutely intoxicated patients under study.

\begin{tabular}{|c|c|c|c|c|}
\hline \multirow[t]{3}{*}{ Clinical variables } & \multicolumn{4}{|c|}{ PTX3 } \\
\hline & \multicolumn{2}{|c|}{ Survivors $(n=22)$} & \multicolumn{2}{|c|}{ Non-survivors $(n=28)$} \\
\hline & $\mathbf{r}$ & $\mathbf{p}$ & $\mathbf{r}$ & $\mathbf{P}$ \\
\hline \multicolumn{5}{|c|}{ Day (1) } \\
\hline APACHE II Score & 0.316 & 0.152 & -0.376 & 0.04 \\
\hline SOFA score & -0.233 & 0.29 & -0.144 & 0.465 \\
\hline LIS & 0.215 & 0.34 & -0.81 & 0.685 \\
\hline No of organ failure & -0.472 & 0.027 & -0.63 & 0.749 \\
\hline $\mathrm{PaO}_{2} / \mathrm{FiO}_{2}$ ratio & 0.171 & 0.446 & 0.196 & 0.318 \\
\hline $\mathrm{SpO}_{2} / \mathrm{FiO}_{2}$ ratio & 0.139 & 0.537 & 0.015 & 0.94 \\
\hline \multicolumn{5}{|c|}{ Day (2) } \\
\hline SOFA score & 0.18 & 0.422 & -0.138 & 0.485 \\
\hline LIS & 0.181 & 0.421 & -0.02 & 0.92 \\
\hline No of organ failure & 0.31 & 0.164 & -0.179 & 0.362 \\
\hline $\mathrm{PaO}_{2} / \mathrm{FiO}_{2}$ ratio & 0.105 & 0.643 & 0.154 & 0.434 \\
\hline $\mathrm{SpO}_{2} / \mathrm{FiO}_{2}$ ratio & 0.198 & 0.377 & -0.021 & 0.96 \\
\hline \multicolumn{5}{|c|}{ Day (5) } \\
\hline SOFA score & 0.298 & 0.178 & -0.281 & 0.148 \\
\hline LIS & 0.28 & 0.192 & -0.331 & 0.085 \\
\hline No of organ failure & 0.171 & 0.446 & -0.055 & 0.779 \\
\hline $\mathrm{PaO}_{2} / \mathrm{FiO}_{2}$ ratio & -0.342 & 0.12 & 0.478 & 0.01 \\
\hline $\mathrm{SpO}_{2} / \mathrm{FiO}_{2}$ ratio & -0.44 & 0.038 & 0.351 & 0.35 \\
\hline
\end{tabular}

n: Number of patients

p $>0.05$ = statistically non-significant r: Correlation coefficient $\mathbf{P}<\mathbf{0 . 0 5}=$ statistically significant

PTX3: Pentraxin 3APACHE II score: Acute Physiology And Chronic Health Evaluation II score

SOFA score: Sequential Organ Failure score LIS: Lung Injury score

$\mathrm{PaO}_{2} / \mathrm{FiO}_{2}$ : Partial arterial oxygen pressure/Fraction of inspired oxygen $\mathrm{SpO}_{2} / \mathrm{FiO}_{2}$ : Pulse oximetric oxygen saturation/Fraction of inspired oxygen 


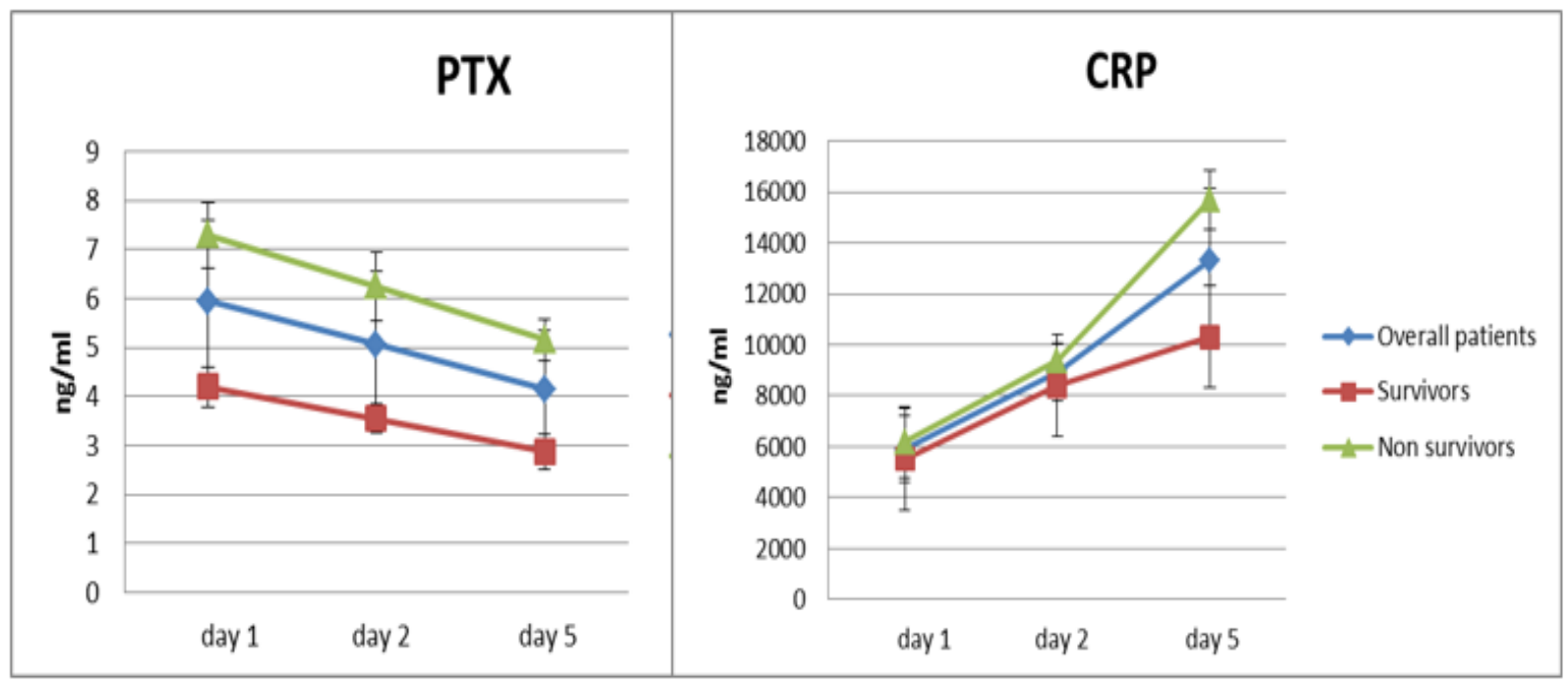

Figure (1): Comparison of plasma PTX3 levels (left) and CRP levels (right) on days 1, 2 and 5 in the surviving and non-surviving intoxicated patients under study.
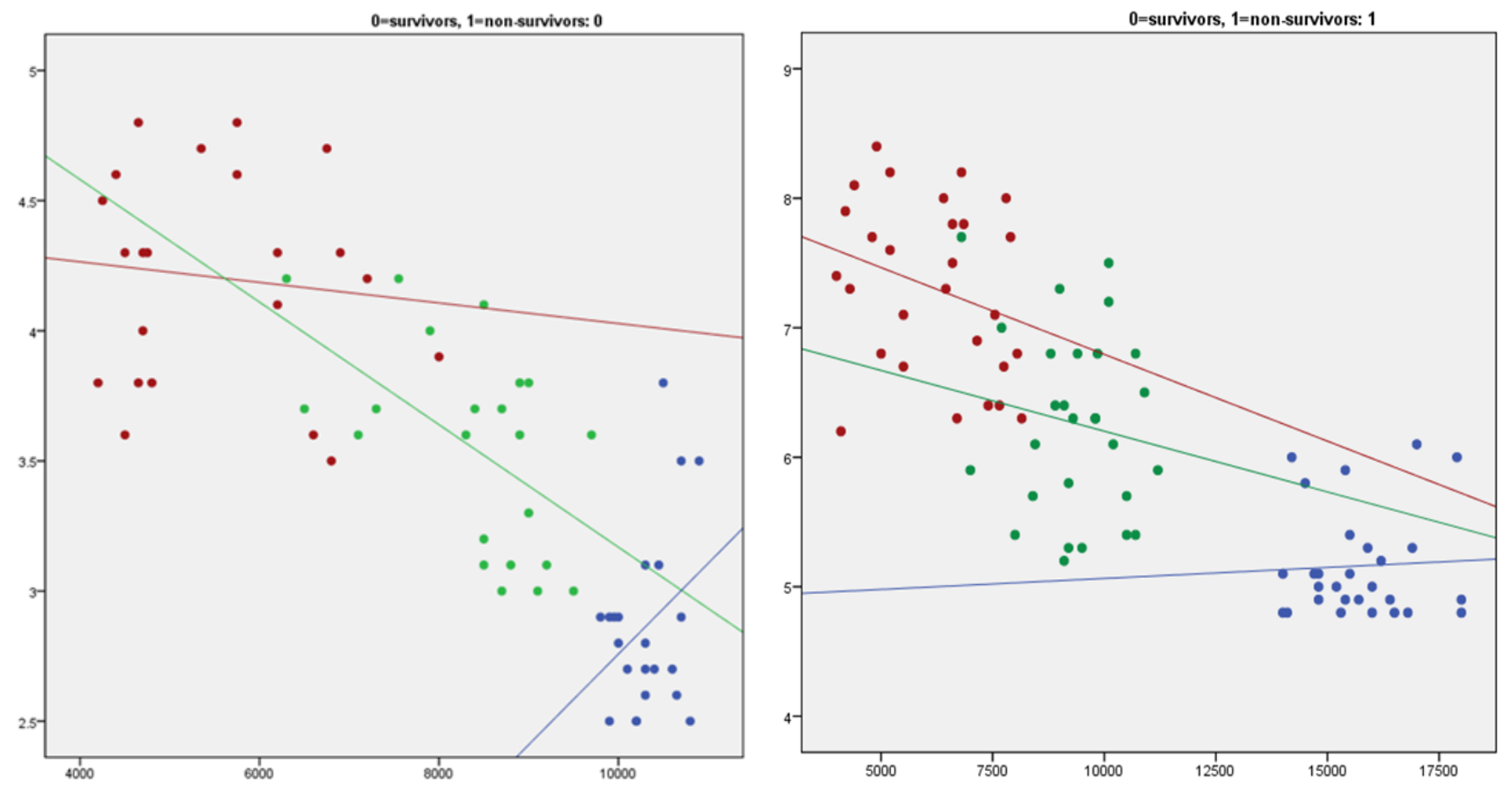

Figure (2): Correlation between PTX3 and CRP among survivors (left) \& non-survivors (right) on different days: Red $=$ day1, Green $=$ day2, Blue=day5

PTX3day1 CRPday1: $\mathrm{R}^{2}$ Linear $=0.012$

PTX3day2 CRPday2: ${ }^{2}$ Linear $=0.296$

PTX3day5 CRPday5: $\mathrm{R}^{2}$ Linear $=0.1$ 


\section{DISCUSSION}

This study was concerned with assessment of severity of various toxin related ALI/ARDS in patients, investigating the value of clinical scores, PTX3 and CRP in prediction and monitoring severity and outcome in ALI/ARDS.

The current study suggests that the type of toxic agents, route of intoxication, and delay time before hospitalization have no significant effect on survival. This may be explained by the ability of lung-damaging toxicants to exert their toxic whether directly by inhalation or indirectly through circulation (De Lange, 2015). Moreover, toxin-related ARDS represents a common pathway of diverse events with no single unifying mechanism existing for all of the xenobiotics implicated (Akgür, 2008; Stolbach \& Hoffman, 2015).

Steroids and neuromuscular blockade were included in the treatment protocol of the studied patients with no significant effect on percentage of death among admitted patients. Similar results were noted by meta-analysis evaluating effects of corticosteroids on ARDS mortality (Ruan et al, 2014). Potential benefits of corticosteroids have been considered aiming at modulation of both pulmonary and systemic inflammatory responses in ARDS (Ruan et al., 2014 \& De Lange, 2015). Yet, those benefits may be counterbalanced by the delayed onset of adverse effects, such as immunosuppression and altered tissue repair especially alveolar (De Lange, 2015). Moreover, diverse responses to corticosteroid treatment could be related to the heterogeneity of activated biochemical and molecular mechanisms in response to different initial insults (Dos Santos, 2008).

Comparable diversity was also documented in the current study regarding the individual response to neuromuscular blockade. It has been suggested that neuromuscular blockade can benefit ARDS patients by eliminating asynchrony and decreasing ventilator-induced lung injury (Hraiech et al., 2014 and Alhazzani et al., 2013). On the other hand, the use of muscle relaxants mostly necessitates concurrent use of sedatives at higher doses, which might interfere with successful weaning trials leading to prolonged duration of mechanical ventilation, ICU length of stay, and increase in mortality (Papazian et al., 2010).

ICU and hospital mortality continues to be the most critical outcome in ARDS clinical studies (Villar and Slutsky, 2017). The overall percentage of death among studied patients was $56 \%$ which was high compared to larger cohort studies (34.9\%-50.4\%) (Bellani et al, 2016). The dose of the involved toxins, the individual variations in response to different types of toxins, complications associating the poisoning itself, the duration of the study, period of treatment delay, treatment facilities, and the patients' response to different treatment modalities may provide possible explanations for differences in outcomes among the currently studied patients.

The recorded data in this study suggested that the cause of mortality in toxin-related ALI/ARDS involved not only respiratory failure but also nonpulmonary organ dysfunction. Previous studies provided evidence which 
attributed the unacceptably high mortality rates in ARDS to multiple organ failure (MOF) rather than severe hypoxemia and respiratory failure (Villar and Slutsky, 2010).

The unequivocal evidence that mechanical ventilation, the mainstay of ARDS treatment, could itself cause and aggravate lung damage in addition to increased incidence of ventilatoracquired pneumonia (VAP), can explain the association of mortality with prolonged ICU stay and mechanical ventilation in the current study (Villar and Slutsky, 2010; Slutsky and Ranieri, 2013; Pan \& Qiu, 2015; Curely et al., 2016).

The contribution of organ failure in mortality and the association of mortality with prolonged ICU stay and mechanical ventilation in the current study bring to mind the cause-effect relation between ventilator-induced lung injury and MOF investigated in numerous clinical and experimental studies. A set of biological processes defined as bio-trauma was postulated: The cyclic over-distension, induced by excessive delivered transpulmonary pressure, may trigger a biological response involving the release of inflammatory mediators that can aggravate lung injury. Moreover, by increasing alveolar-vascular permeability, mechanical ventilation could contribute to decompartmentalization of the inflammatory cascade primarily initiated in the lungs, leading to systemic organ dysfunction affecting mortality (Ranieri et al. 1999; Suchyta 2003; Tremblay and Slutsky 2006; Del Sorbo and Slutsky, 2011).
Circulatory failure is a frequent complication in ARDS and is independently associated with death (Vieillard-Baron et al, 2010). Our study was no different as cardiovascular affection accounting for $57 \%$ of mortalities, followed by renal and hepatic dysfunction, with a single case of hematological affection in the form of thrombocytopenia. Circulatory failure can be either related to the frequently associated septic shock or ARDS-related right ventricular failure. Pulmonary vascular dysfunction inherent to the disease, ill-adapted ventilatory strategies, and septic cardiomyopathy contribute to the occurrence of right ventricular dysfunction/failure leading to further organ dysfunction and poor outcome (Price et al, 2012; Paternot et al, 2016).

As suggested by a met analysis by Van den Akker et al (2013), both ARDS and mechanical ventilation were associated with a 3-fold increase in the risk of acute kidney injury, with dramatical increase in mortality. In comparison to the current study, some authors reported even higher incidence of renal affection in ARDS patients (Liu et al, 2008; Cooke et al, 2008 and Darmon et al, 2014). Three main underlying mechanisms were proposed namely: positive-pressure ventilation, hypoxemia, and systemic inflammation. First, positive-pressure ventilation may reduce cardiac output and increase central venous pressure, thereby diminishing renal blood flow, free water clearance, or the GFR. Moreover, activation of the sympathetic and reninangiotensin systems, together with suppression of atrial natriuretic peptide release, observed during positive 
pressure ventilation further decreases glomerular perfusion, GFR values, urine output, and sodium excretion Additionally, hypoxemia and hypercapnia were also shown to modify renal vascular resistances and to increase diuresis (Darmon et al ,2014). Finally, propagation of systemic inflammation and release of inflammatory cytokines (Imai et al, 2003)

Among associated organ failures, hepatic dysfunction complicating ARDS has been poorly studied .Similar to the current study, Sheu et al. (2010) and Dizier et al. (2015) have shown a relationship between hepatic dysfunction and poor outcome in ARDS patients. The effect of ARDS on the liver may result from the association of microvascular hepatic injury, increased permeability and intrahepatic edema which in turn may interfere with adequate hepatic cellular oxygenation resulting in hepatocellular damage (Possamai et al., 2010 and Rubenfeld and Herridge, 2007).

In the current study, the occurrence of thrombocytopenia as a consequence of ARDS was not unexpected. This could be justified by the role of lungs as reservoirs for megakaryocytes, the requisite precursor cell in thrombopoiesis and a suggested site of platelet biogenesis (Weyrich and Zimmerman, 2013).

In the absence of a direct reliable marker of lung injury, gas exchange is commonly used as an indicator of lung function in critically ill patients. For many years, physicians have relied on $\mathrm{PaO} 2 / \mathrm{FIO} 2$ ratio as a central element to define ARDS and characterize its severity. In addition, it is utilized to track change in lung conditions, to set PEEP, to assess the response to different ventilatory strategies and/or to make decision regarding the need for advanced supportive treatment modalities (Broccard , 2013 ; Villar et al, 2013). Despite having the merit of simplicity and availability, the reality at the bedside is more complex than acknowledged. On the 1st day of the present study, hypoxemic indices did not show statistically significant difference between survivors and non survivors though higher mean values were observed among survivors. However, a significant difference between both groups became obvious on the following days.

This can be viewed according to Villar et al. (2015) who concluded that, the stratification of patients with ARDS based on the initial value of $\mathrm{PaO} 2 / \mathrm{FiO} 2$ ratio at the time of ARDS diagnosis, or based on the non-standardized value of $\mathrm{PaO} 2 / \mathrm{FiO} 2$, is not useful for assessing severity of lung injury. The risk of misinterpretation of the $\mathrm{PaO} 2 / \mathrm{FIO} 2$ was also highlighted by Broccard (2013) based on the fact that the calculated $\mathrm{PaO} 2 / \mathrm{FiO} 2$ can be easily manipulated by changing FiO2, Vt and PEEP or change for reasons that are completely independent of the lungs (e.g. a change in $\mathrm{CO}$ and mixed venous $\mathrm{O} 2$ ).

The improved correlation between hypoxemic indices and mortality beyond 24 hours supports the two-step approach for assessment of ARDS suggested by Villar et al. (2015) where reassessment of $\mathrm{PaO} 2 / \mathrm{FiO} 2$ especially under standardized ventilatory settings represents a better method to identify and differentiate groups of patients at highest 
risk for adverse clinical outcomes independent of the underlying disease or specific therapy applied.

In the current study, a positive significant correlation was found between $\mathrm{PaO} 2 / \mathrm{FiO} 2$ and $\mathrm{SpO} 2 / \mathrm{FiO} 2$ ratios among survivors and non survivors on day (5). Based on similarly recorded correlations, the use of $\mathrm{SpO} / \mathrm{FiO} 2$ ratio was recommended as a reliable noninvasive surrogate for $\mathrm{PaO} 2 / \mathrm{FiO} 2$ ratio in the diagnosis and follow up of ALI and ARDS patients with the advantage of replacing invasive arterial blood sampling $(\mathrm{ABG})$ by non-invasive pulse oximetry (Rice et al., 2007 ; Bilan et al., 2015 ; Sahasrabhojney et al,2015).

Several ICU scoring systems were designed to help defining critically ill patients, estimating their prognosis, clinical decision making, guiding the allocation of resources, comparing quality-of-care and patient stratification for clinical trials (Vincent and Moreno, 2010). Regarding ARDS, most of the available scores are comparable in terms of outcome prediction and seem complementary to each other (Raghavendran and Napolitano, 2011).

An initially high APACHE II score was observed in the current study reflecting the degree of severity at the time of admission in the ICU. This finding is reasonable owing to the ICU admission policy which is restricted to critically ill, unstable patients and those in need of intensive management and continuous monitoring.

The present study showed the superior discriminating power of APACHE II score over SOFA score and LIS in the initial stratification of patients of toxin-related ALI/ARDS according to severity in relation to mortality. An APACHE II score exceeding 21 was found to be sensitive and specific predictor for mortality. Similarly, the APACHE II severity score has shown a good calibration and discriminatory value across a range of disease processes, and remains the most commonly used international severity scoring system worldwide (Sekulic et al.,2015).

The observed lower sensitivity and specificity of LIS on the 1st day of the study, compared to APACHE II score could be attributed to its components focusing only on respiratory variables while MOF remains a predominant cause of hospital mortality in the cases enrolled in the study. However, LIS also showed a statistically significant difference between survivors and non survivors on the following days. This finding is important, as LIS may be more suited to discriminate pulmonary-specific outcome and can be linked to the predominance of respiratory failure in all non survivors despite the presence of other organ affection. These findings are consistent with the identification of LIS as an independent predictor of developing ARDS after one day of standardized ventilator management by Villar et al. (2007), and its ability to predict pulmonary outcomes noted by Kangelaris et al. (2014).

On the other hand, limitations for the usefulness of LIS was suggested by a number of studies Bauman et al., (2015) which highlighted the importance of non-pulmonary factors, including age, severity of sepsis, concurrent comorbidities and non-pulmonary organ 
failure, as the most influential predictors of mortality in ARDS rather than the individual severity scoring systems. These limitations can be taken into consideration in the interpretation of results in later days of the study, as both SOFA score and LIS showed oscillating sensitivity and specificity which may reflect the clinical instability of the studied patients where clinical deterioration might follow an initial deceptive improvement.

Regarding SOFA score, a statistically significant difference between survivors and non survivors was noted on all days, owing to the increased incidence of multi-organ dysfunction among non survivors though it also showed a relatively lower sensitivity and specificity compared to APACHE II score in predicting mortality.

At the end of the present study, SOFA score and LIS became 100\% sensitive and specific at cut off value of 5.5 and 1.38 respectively with excellent AUC values (1.0). From this perspective, both SOFA score and LIS van be considered as late predictors of mortality. This is to be compared to the early highly sensitive and specific APACHE II score which was similarly confirmed by Ho (2007) and Kao HC et al., (2013).

The present study demonstrated significantly elevated PTX and CRP in toxin-related ARDS patients with an inverse significant correlation on the 2 nd day. This reflected their reciprocal course. PTX peaked on the first day and, although its levels dropped on day (2) and day (5), they did not return to the normal values. In contrast to the early increase in PTX3, CRP levels started to increase on the 2nd day with the peak on the 5th day of the present study.

PTX3 and CRP were significantly higher among non survivors compared to survivors. Out of recorded first day variables, PTX3 showed 100\% sensitivity and specificity with a cut off value of $5.5 \mathrm{ng} / \mathrm{ml}$ and AUC of 1.0 , announcing itself as a promising early predictor of mortality in cases of toxininduced ARDS. Owing to its delayed peak, early measured CRP had less sensitivity and specificity in predicting mortality in the studied patients, in comparison to PTX3. Furthermore, while CRP reached a reliable sensitivity and specificity on the fifth day of the study, PTX3 proved its superiority in distinguishing survivors from non survivors with $100 \%$ accuracy on all recorded days.

In accordance to our findings, a number of authors have reported increased levels of PTX3 in ARDS, and its role a useful early predictor of survival (Mauri et al., 2008; Mauri et al., 2014; Uusitalo-Seppälä et al., 2013and Ahiskalioglu et al., 2015).

These findings can be explained in light of studies addressing the role of PTX in ALI/ARDS. PTX3 is an acute phase protein and has been shown to plays a key role not only in innate immunity, but also as a tuner of inflammation. It recognizes different injurious noxae and secures greater neutrophil influx into the lung in addition to increased nitric oxide production and tissue factor expression. Moreover, it was suggested that persistent tissue damage, prolonged mechanical ventilation and severe infections cause PTX3 overexpression with detrimental 
amplification of the above mentioned inflammatory pathways resulting in poor outcomes (He et al.,2007;Cribbs and Martin, 2008 and Mauri et al., 2008).

In view of the diversity of pathophysiological background of toxinrelated ARDS, predicting outcome may be challenging. The current study suggest interesting correlations between PTX3 and clinical variables that describe both severity of lung impairment and systemic involvement. Among survivors, with the exception of the initial SOFA score, a positive correlation between PTX and all recorded scores was found on all days. The negative correlation observed with SOFA score can be justified by the precocious peak of PTX levels versus initial low SOFA scores. Regarding non survivors, PTX was inversely correlated with all scores on all days. These results demonstrate the close association of PTX levels with clinical outcome and severity of toxin-related ALI/ARDS. Moreover, this study provides a strong evidence that a combination of biomarkers and clinical predictors can provide higher prognostic index for mortality in toxin-related ARDS in comparison of either of them alone.

Similar results were obtained by Ahiskalioglu et al., (2015) where PTX3 were positively correlated with APACHE II score. On the other hand, a study carried out by Kao SJ et al., (2013) and Liu et al., (2014) on patients with community-acquired pneumonia and sepsis respectively revealed a positive correlation between PTX3 and APACHE II score, explaining this by the high specificity of PTX3 and APACHE II score not only in the diagnosis, but also in the clinical assessment of the severity of various infectious diseases.

\section{CONCLUSION}

Toxin-related ALI/ARDS is considered one of the devastating, fatal conditions with $56 \%$ mortality rate. Age and gender of the poisoned patients, type of toxic agents and serum CRP levels within the $1^{\text {st }} 24$ hours of admission seem to have no effect on outcome in toxin-related ARDS. Several variables were associated with poor outcome including prolonged ICU stay, prolonged duration of mechanical ventilation, low $\mathrm{PO}_{2} / \mathrm{FiO}_{2}$ and $\mathrm{SO}_{2} / \mathrm{FiO}_{2}$ ratios, high APACHE II, SOFA and lung injury scores on the $1^{\text {st }}$ day, elevated plasma PTX3 levels on the $1^{\text {st }}$ day, and elevated serum CRP levels after 24 hours of admission. The novel biomarker PTX3 was impressively elevated in toxinrelated ALI/ARDS patients and correlated with parameters of lung injury, systemic organ failure and outcome, representing an early marker of severity. APACHE II score surpassed SOFA score and LIS as an excellent predictor of outcome within the $1^{\text {st }} 24$ hours of admission. The early combination of plasma PTX3 and predictive scores could help in risk stratification and prediction of mortality in poisoned ARDS patients.

\section{REFERENCES}

Ahiskalioglu, E.O.; Dogan, N., Kiziltunc, A., Ahiskalioglu, A., Coskun, A.S., Kursad, H. and Aksoy, M. (2015): Is Pentraxin-3 an early biomarker of primary acute respiratory distress syndrome in the intensive care unit? A prospective 
study. Acta Medica Mediterranea, 31: 639-645.

Akgür, S.A.; Veral, A., and Ege, B. (2008): Adult respiratory distress syndrome in human organophosphate poisoning cases. Toxicological \& Environmental Chemistry, 90 (3):493-499.

Alhazzani, W.; Alshahrani, M., Jaeschke, R., Forel, J.M., Papazian L, Sevransky J, and Meade, M.O., (2013): Neuromuscular blocking agents in acute respiratory distress syndrome: a systematic review and meta-analysis of randomized controlled trials Critical Care, 17:R43.

Bauman, Z.M.; Gassner, M.Y., Coughlin, M.A., Mahan, M., and Watras, J. (2015): Lung Injury Prediction Score is useful in predicting acute respiratory distress syndrome and mortality in surgical critical care patients. Crit Care Res Pract, 1-8.

Bilan, N.; Dastranji, A. and Behbahani, A.G., (2015):

Comparison of the Spo2/Fio2 Ratio and the Pao2/Fio2 Ratio in patients with acute lung injury or acute respiratory distress syndrome. J Cardiovasc Thorac Res, 7(1), 28-31.

Bottazzi, B.; Garlanda, C., Cotena, A., , Moalli, F., Jaillon, S., Deban, L., and Mantovani, A. (2009): The long pentraxin PTX3 as a prototypic humoral pattern recognition receptor: interplay with cellular innate immunity. Immunol Rev, 227, 9-18.

Broccard, A.F. (2013): Making sense of the pressure of arterial oxygen to fractional inspired oxygen concentration ratio in patients with acute respiratory distress syndrome. OA Critical Care, 1(1), 9.

Cooke, C.R.; Kahn, J.M., Caldwell, E., Okamoto, V.N., Heckbert S.R., Hudson, L.D., and Rubenfeld G.D. (2008): Predictors of hospital mortality in a population-based cohort of patients with acute lung injury. Critical care medicine, 36(5), 1412-20.

Cribbs, S.; and Martin, G. (2008): Biomarkers in acute lung injury: Are we making progress? Crit Care Med, 36(8), 2457-2459.

Curley, G.F., Laffey, J.G., Zhang, H. and Slutsky, A.S. (2016): Biotrauma and ventilator-induced lung injury: clinical implications. Chest, 150(5), 11091117.

Cypel, M.; Mura, M. and Zhang, Y. (2010): PTX3 as a potential biomarker of acute lung injury: Supporting evidence from animal experimentation. Intensive Care Med, 36(2), 356-364.

Darmon, M.; Clec'h, C., Adrie, C., Argaud, L., Allaouchiche, B., Azoulay, E., Bouadma, L., Garrouste-Orgeas, M., Haouache, H., Schwebel, C., and GoldgranToledano, D. (2014): Acute respiratory distress syndrome and risk of AKI among critically ill patients. Clinical Journal of the American Society of Nephrology, 9(8), 1347-53.

De Lange, D.W. (2015): Treatment of Acute Respiratory Distress Syndrome in the Poisoned Patient. In : Brent J, Burkhart K, Dargan P, Hatten B, Megarbane B, Palmer $\mathrm{R}$, and White $\mathrm{J}$, eds. Critical Care 
Toxicology: Diagnosis and Management of the Critically Poisoned Patient. Switzerland: Springer International Publishing.

Del Sorbo, L. and Slutsky, A.S. (2011): Acute respiratory distress syndrome and multiple organ failure. Curr Opin Crit Care, 17, 1-6.

Dizier, S.; Forel, J.M., Ayzac, L., Richard, J.C., Hraiech, S., Lehingue, S., Loundou, A., Roch, A., Guerin, C., Papazian, L. and ACURASYS study investigators (2015): Early hepatic dysfunction is associated with a worse outcome in patients presenting with acute respiratory distress syndrome: a post-hoc analysis of the ACURASYS and PROSEVA studies. PloS one, 10(12):e0144278.

Dos Santos, C.C. (2008): Advances in mechanisms of repair and remodeling in acute lung injury. Intensive Care Med, 34, 619-30.

Fanelli, V.; Vlachou, A., Ghannadian, S., Simonetti, U., Slutsky, A.S., and Zhang, H. (2013): Acute respiratory distress syndrome: new definition, current and future therapeutic options. Journal of thoracic disease, $5(3), 326-34$.

Goris, R.J., te Boekhorst, T.P., Nuytinck, J.K., and Gimbrère, J.S. (1985): Multiple-organ failure. Generalized autodestructive inflammation? Arch Surg, 120, 1109-1115.

He, X., Han, B., and Liu, M. (2007). Long pentraxin 3 in pulmonary infection and acute lung injury. Am J Physiol Lung Cell Mol Physiol, 292, L1039-L 1049.

Ho, K.M. (2007): Combining sequential organ failure assessment (SOFA) score with acute physiology and chronic health evaluation (APACHE) II score to predict hospital mortality of critically ill patients. Anaesthesia Intensive Care, 35(4), 515-521.

Hraiech, S.; Dizier, S., and Papazian, L. (2014): The use of paralytics in patients with acute respiratory distress syndrome. Clin Chest Med. 35(4), p.753-63.

Huttunen, R.; Hurme, M., Aittoniemi, J., Huhtala, H., Vuento, R., Laine, J., Jylhävä, J., and Syrjänen, J. (2011): High Plasma Level of Long Pentraxin3 (PTX3) Is Associated with Fatal Disease in Bactremic Patients: A Prospective Cohort Study. PLoS ONE, 6(3), p. 1-6.

Imai, Y.; Parodo, J., Kajikawa, O., de Perrot, M., Fischer, S., Edwards, V., Cutz, E., Liu, M., Keshavjee, S., Martin, T.R., Marshall, J.C., Ranieri, V.M., and Slutsky, A.S. (2003): Injurious mechanical ventilation and end-Organ epithelial cell apoptosis and organ dysfunction in an experimental model of acute respiratory distress syndrome. JAMA, 289(16), p.21042112.

Kangelaris, K.N.; Calfee, C.S., May, A.K., Zhuo, H., Mattha, M.A., and Ware, L.B. (2014): Is there still a role for the lung injury score in the era of the Berlin definition ARDS? Ann intensive care, 4(1), p.4.

Kao; H.C., Lai, T.Y., Hung, H.L., Chen, Y.M., Chou, P.A., Wang, C.C., Lin, M.C., and Fang, W.F. (2013): Sequential Oxygenation Index and Organ Dysfunction 
Assessment within the First 3 Days of Mechanical Ventilation Predict the Outcome of Adult Patients with Severe Acute Respiratory Failure. Sci World J, 1-10.

Kao, S.J.; Yang, H.W., Tsao, S.M., Cheng, C.W., Bien, M.Y., Yu, M.C., Bai, K.J., Yang, S.F., and Chien, M.H. (2013): Plasma long pentraxin 3 (PTX3) concentration is a novel marker of disease activity in patients with community-acquired pneumonia. Clin Chem Lab Med, 51(4), 907-913.

Knaus, W.A., Zimmerman, J.E., Wagner, D.P., Draper, E.A., and Lawrence, D.E. (1981); APACHEacute physiology and chronic health evaluation: A physiologically based classification system. Crit Care Med, 9, 591-7.

Liu, K.D. and Matthay, M.A. (2008): Advances in Critical Care for the Nephrologist: Acute Lung Injury/ARDS. Clin J Am Soc Nephrol, 3, 578-586.

Liu, S.; Ren, J., Xia, Q., Wu, X., Han, G., Ren, H., Yan, D., Wang, G., Gu, G., and Li, J. (2013): Preliminary case-control study to evaluate diagnostic values of $\mathrm{C}$ reactive protein and erythrocyte sedimentation rate in differentiating active Crohn's disease from intestinal lymphoma, intestinal tuberculosis and Behcet's syndrome. Am J Med Sc, 346(6), 467-472.

Liu, S.; Qu, X., Liu, F., and Wang, C. (2014): Pentraxin 3 as a prognostic biomarker in patients with systemic inflammation or infection. Med Inf, $1-9$.

Mauri, T.; Coppadoro, A., Bellani, G.,
Bombino, M., Peri, G., Mantovani, A. and Pesenti, A. (2008): Pentraxin 3 in acute respiratory distress syndrome: an early marker of severity. Crit Care Med, 36(8), 23028.

Mauri, T.; Coppadoro, A., Bombino, M., Bellani, G., Zambelli, V., Fornari, C., Berra, L., Bittner, E.A., Schmidt, U., Sironi, M. and Bottazzi, B. (2014): Alveolar pentraxin 3 as an early marker of microbiologically confirmed pneumonia: a threshold-finding prospective observational study. Crit Care, 18, 562.

Murray, J.F.; Matthay, M.A., Luce, J.M., and Flick, M.R. (1988): An expanded definition of the adult respiratory distress syndrome. Am Rev Respir Dis, 138(3), 720-723.

Papazian, L.; Forel, J.M., Gacouin, A., Penot-Ragon, C., Perrin, G., Loundou, A., Jaber, S., Arnal, J.M., Perez, D., Seghboyan, J.M. and Constantin, J.M., (2010): Neuromuscular blockers in early acute respiratory distress syndrome. N Engl J Med, 363(12), 1107-16.

Possamai, L.A., Antoniades, C.G., Anstee, Q.M., Quaglia, A., Vergani, D., Thursz, M. and Wendon, J. (2010): Role of monocytes and macrophages in experimental and human acute liver failure. World J Gastroenterol, 16(15), 1811-9.

Price, L.C.; McAuley, D.F., Marino, P.S., Finney, S.J., Griffiths, M.J., and Wort, S.J. (2012): Pathophysiology of pulmonary hypertension in acute lung injury. American Journal of Physiology- 
Lung Cellular and Molecular Physiology, 302(9), L803-15.

Raghavendran, K., and Napolitano, L.M. (2011): "Definition of ALI/ARDS." Critical care clinics, 27(3), 429-437.

Ranieri, V.M., Suter, P.M., Tortorella, C., De Tullio, R., Dayer, J.M., Brienza, A., Bruno, F. and Slutsky, A.S. (1999): Effect of mechanical ventilation on inflammatory mediators in patients with acute respiratory distress syndrome: a randomized controlled trial. JAMA, $282,54-61$.

Pan, C. and Qiu. H. (2015): Improve survival from prolonged mechanical ventilation: beginning with first step. J Thorac Dis, 7(7), 1076-1079.

Paternot, A.; Repessé, X. and Vieillard-Baron, A. (2016): Rationale and Description of Right Ventricle-Protective Ventilation in ARDS. Respiratory Care, 61(10), 1391-6.

Raissy, H.H. and Harkins, M. (2014): Drug-Induced Pulmonary Diseases. In: DiPiro JT, Talbert RL, Yee GC, Matzke GR, Wells BG, and Posey L. eds. Pharmacotherapy: A Pathophysiologic Approach, 9e New York: McGraw-Hill, 235-249.

Rice, T.W.; Wheeler, A.P., Bernard, G.R., Hayden, D.L., Schoenfeld, D.A. and Ware, L.B. (2007). Comparison of the $\mathrm{SpO} 2 / \mathrm{FIO} 2$ ratio and the $\mathrm{PaO} 2 / \mathrm{FIO} 2$ ratio in patients with acute lung injury or ARDS. CHEST Journal, 132(2), 410-7.

Ruan, S.Y.; Lin, H.H., Huang, C.T., Kuo, P.H., Wu, H.D. and Yu, C.J. (2014): Exploring the heterogeneity of effects of corticosteroids on acute respiratory distress syndrome: a systematic review and meta-analysis. Critical care, 18(2), R63.

Rubenfeld, G. and Herridge, M. (2007): Epidemiology and outcomes of acute lung injury. CHEST J, 131(2), p.554-562.

Sahasrabhojney, V.; Game, P.D., Chand, D., Meshram, V., Kharade, M. and Deotale, R. (2015): $\mathrm{SpO} / \mathrm{FiO} 2$ ratio: a prognostic marker for influenza patients .Int $\mathbf{J}$ Res Med Sci., 3(12), 3830-3832.

Sekulic, A.D.; Trpkovic, S.V., Pavlovic, A.P., Marinkovic, O.M. and Ilic, A.N. (2015): Scoring systems in assessing survival of critically ill ICU patients. Medical science monitor: international medical journal of experimental and clinical research, 21, 2621.

Sheu, C.C.; Gong, M.N., Zhai, R., Chen, F., Bajwa, E.K., Clardy, P.F., Gallagher, D.C., Thompson, B.T. and Christiani, D.C. (2010): Clinical Characteristics and Outcomes of Sepsis-Related vs NonSepsis-Related ARDS. CHEST J, 138(3), 559-567.

Stolbach, A. and Hoffman, R.S. (2015): Respiratory principles. In: Hoffman RS, Howland MA, Lew in NA, et al., eds. Goldfrank's Toxicologic Emergencies, 10th edition. New York: McGraw-Hill, 366-376.

Suchyta, MR. (2003): The changing face of organ failure in ARDS. CHEST J, 124, 1871-1879.

Tremblay, L.N. and Slutsky, A.S. (2006): Ventilator-induced lung injury: from the bench to the bedside. Intensive Care Med, 32, 24- 


\section{3.}

Udobi, K.; Childs, E. and Touijer, K. (2003): Acute Respiratory Distress Syndrome. Am Fam Physician, 67(2), 315-322.

Uusitalo-Seppälä, R.; Huttunen, R., Aittoniemi, J., Koskinen, P., Leino, A., Vahlberg, T. and Rintala, E.M. (2013): Pentraxin 3 (PTX3) is associated with severe sepsis and fatal disease in emergency room patients with suspected infection: a prospective cohort study. PLoS One, 8(1), e53661.

Van den Akker, J.P.; Egal, M. and Groeneveld, A.J. (2013): Invasive mechanical ventilation as a risk factor for acute kidney injury in the critically ill: a systematic review and meta-analysis. Critical care, 17(3), R98.

Vincent, J.L.; de Mendonça, A., Cantraine, F., Moreno, R., Takala, J., Suter, P.M., Sprung, C.L., Colardyn, F. and Blecher, S. (1996): The SOFA (Sepsis-related Organ Failure Assessment) score to describe organ dysfunction/failure. On behalf of the Working Group on Sepsis-Related Problems of the European Society of Intensive Care Medicine. Intensive Care Med, 22, 707-10.

Vincent, J. and Moreno, R. (2010): Clinical review: Scoring systems in the critically ill. Crit Care, 14(2), p. 207.

Villar, J.; Pérez-Méndez, L., López, J., Belda, J., Blanco, J., Saralegui, I., Suárez-Sipmann, F., López, J.,
Lubillo, S. and Kacmarek, R.M. (2007): An early PEEP/FIO2 trial identifies different degrees of lung injury in patients with acute respiratory distress syndrome. American journal of respiratory and critical care medicine, 176(8), 795804.

Villar, J.; Pérez-Méndez, L., Blanco, J., Añón, J.M., Blanch, L., Belda, J., Santos-Bouza, A., Fernández, R.L. and Kacmarek, R.M. (2013): A universal definition of ARDS: the $\mathrm{PaO} 2 / \mathrm{FiO} 2$ ratio under a standard ventilatory setting - a prospective, multicenter validation study. Intensive Care Med, 39(4), 583-592.

Villar, J.; Fernández, R.L., Ambrós, A., Parra, L., Blanco, J., Domínguez-Berrot, A.M., Gutiérrez, J.M., Blanch, L., Añón, J.M., Martín, C. and Prieto, F. (2015): A clinical classification of the acute respiratory distress syndrome for predicting outcome and guiding medical therapy. Crit Care Med, 43(2), 346-353.

Vieillard-Baron, A.; Bouferrache, $\mathbf{K}$. and Charron, C. (2010): Right ventricular function evaluation in acute respiratory distress syndrome: Back to the future. Critical care medicine, 38(9), 1909-1910.

Ware, L.B., and Matthay, M.A. (2000): The acute respiratory distress syndrome. N Engl J Med, 342, 1334-1349.

Weyrich, A.S., and Zimmerman, G.A. (2013): Platelets in Lung Biology. Annu Rev Physiol, 75, 569-591. 


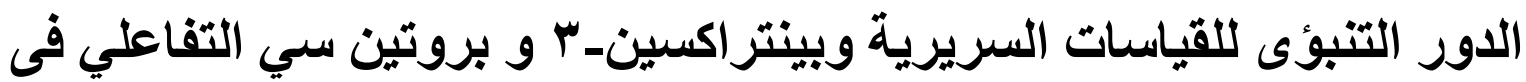

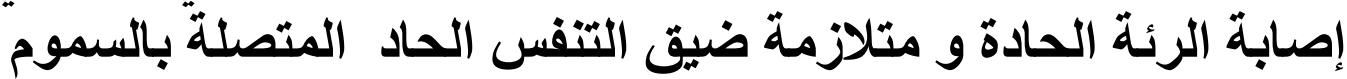

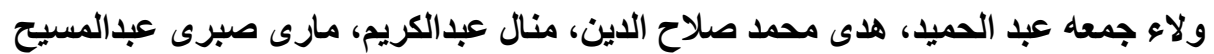 مركز السموم، قسم الطب الثرعى والسموم الاكلينكية، كلية الطب، جامعة عين شمس، الثري، القاهرة}

الأهداف: تشكل إصـابة الرئة الحادة و /أو متلازمة ضيق التتفس الحاد المتصلة بالسموم تحديا لأطباء

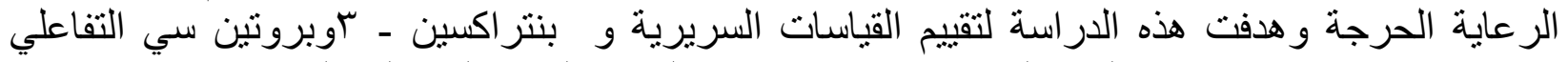
كمتنبئات بشدة ونتيجة إصابة الرئة الحادة و متلازمة ضيق التنفس الحاد المتصلة بالسموم في لـه مريضا مصابين بالتسمح الحاد.

المنهج: تم تقييم المتغير ات المختبرية في اليوم الأولهو الثانى، و الثالث و نقطة النهاية. كما تم استخدام البيانات السريرية في احتساب مقياس أباتشي الثاني ، ومقياس درجة إصابة الرئة الحادة، ومقياس تقييم الفثل ونل العضوى المثتابع. النتائج: ارتبطت عدة متغير ات بالنتائج السيئة في مرضى متلازمة ضيق التنفس الحاد المتعرضين

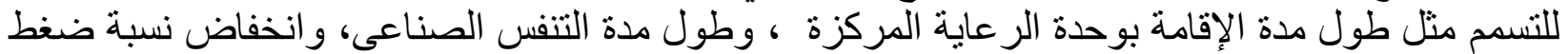

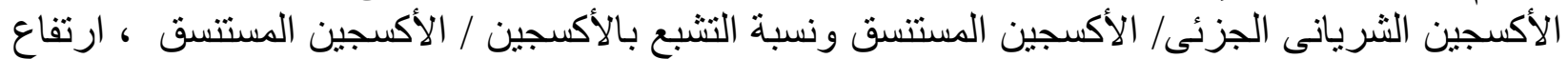

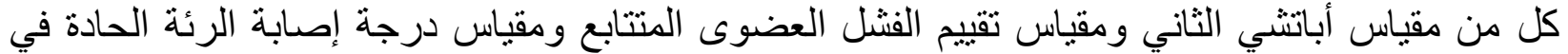

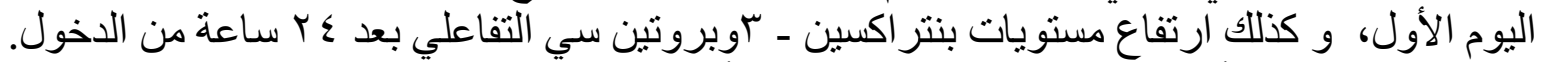

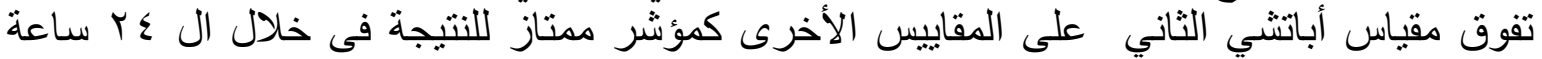

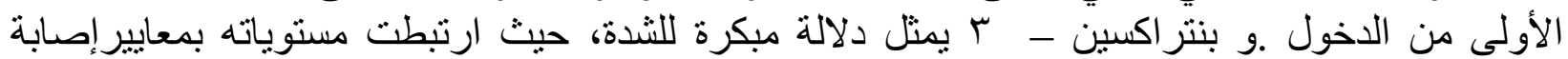
الرئة،و فثل الأعضاء الجهازي الأوب والنتيجة. الاستنتاج: يمكن للجمع ألمبكر بين كل من بنتزر اكسين - ب م والقياسات التنبؤية أن يساعد في تحديد المرضى المعرضين لخطر الإصابة الثديدة و المميتة بمتلازمة ضين المين التنفس الحاد المتصلة بالسموم . 